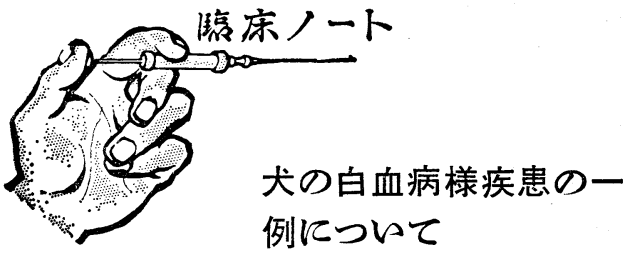

八木 広*

（昭和 43 年 2 月 9 日受付）

白血病は人畜ともに，必ずしも多い疾患ではないが， 予後は不良のものが多い，人の白血病の報告 $7,8,12,13)$ は 多数見らけられ, 家畜に括いても近年鷄, 牛の被害が 重要視されている.鷄の白血病については, すでに石 谷ら2)の詳細な報告があり，また高頼4)扣よび藤井ら2) はそれぞれ牛の淋巴性白血病について報告している。さ らに其田ら15)は馬について, 生前明らかに診断した淋巴 性白血病の詳細な報告をしている。家畜における白血病 は, 成書によれば, 牛馬豚に比べ犬にその発症が多いと いわれるが，わが国では，鳥潟ら1の報告をみるに過ぎ ない. A.C. AsBURG3)はその臨床経過をかなり詳細に追 求している.

筆者は 1967 年 3 月に, 白血球が異常に增加し, 慢性 白血病を疑がわしめる患犬に遭遇し， 3 週間余にわたっ て診療する機会を得たので，その臨床経過について報告 し諸賢の御批判を得たい。

1. 症例 ドイッシェパード種, ㅇ, 5 才

2. 禀告 昭和 41 年 2 月 ( 4 才時) 飞歩行時顛倒, 血尿, 呼吸困難などの症状で, 某獣医師の診療をらけ, フィラリア症の診断のもとに 18 日間治療をうけて治 痛. その後約 10 日を経て同様の症状が再発. さらに22 日間治療をらけ治痖した，その後削瘦が続き，栄養の恢 復はみられなかった，その後間もなく現住地に転居し， この頃から消化不良性の軟便が続き, 栄養障害が著明で さらに削瘦し，倦总感もはなはだしくなった。

\section{3. 初診時の臨床症状}

体温 $39.4^{\circ} \mathrm{C}$, 脈拍数 120 , 呼吸数 56 , 全身が細かく ふるえ, 聴診では心音は鈍く, 心尖部に著明な雑音を認 めた. 結膜, 口粘膜など可視粘膜は蒼白で著るしい貧血 症状を呈していた。静止時でも呼吸は促迫し, わずかな 歩行運動でも促迫状態ははなはだしく顕著となった。ま た血尿と少量の鼻出血を認めた.

腹部は澎満し, 左最後位肋骨の後縁にそって硬固な腫 瘤 (後に試験開腹で巨大脾腫を確認)を触知, 該部を軽 く圧すると疼痛を訴劣た。

血液, 尿検査成績は第 1 表に示すごとく, 赤血球数 $324 \times 10^{4}, \mathrm{Hb}$ 值 $39 \%$, 白血球数 89,700 , 総蛋白量

* 東京都 開業
第 1 表 臨床 検 查成 績

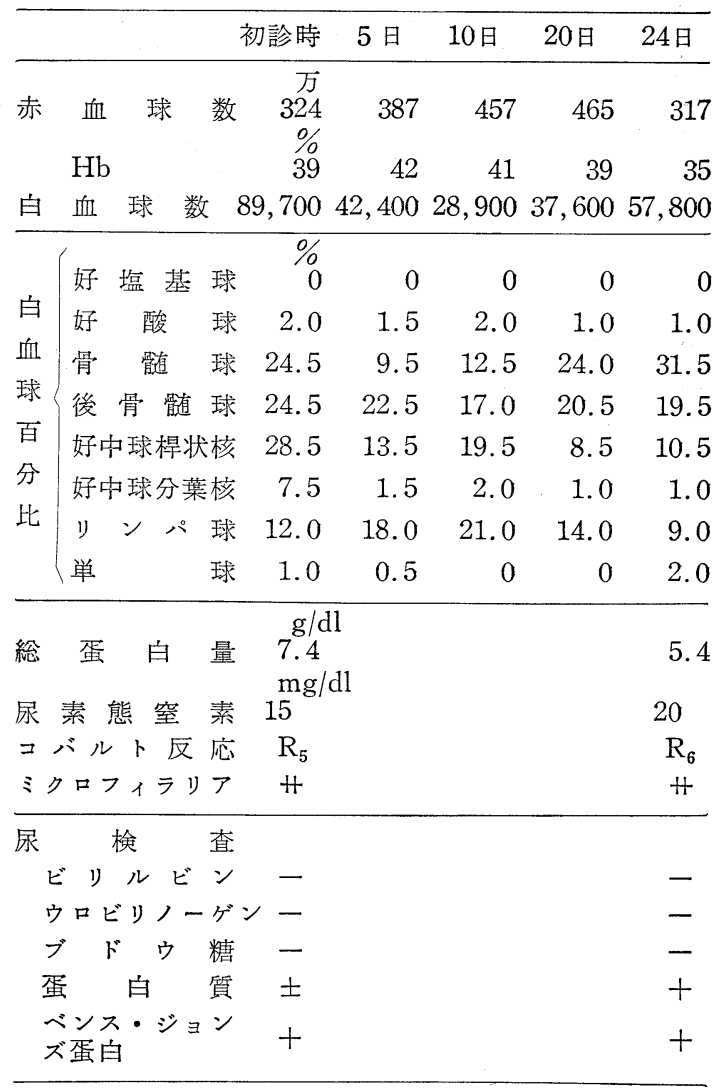

$7.4 \mathrm{~g} / \mathrm{dl}$, 白血球百分比では, 好塩基球 $\mathrm{O}$, 好酸球 2.0 , 骨髄球 24.5 , 後骨髄球 24.5 , 好中球桿状核 28.5 , 分 葉核 7.5 , リンパ球 12.0 , 単球 $1.0 \%$ であった。 コバ ルト反応は $\mathrm{R}_{5}$ で, 血清尿素態窒素 $15 \mathrm{mg} / \mathrm{dl}$, ミクロフ イラリア陽性であった。

尿検査成績は, ビリルビン, ウロビリノーゲン，糖と も検出されず, 蛋白のみ陽性で, ベンス・ジョンズ蛋白 も陽性であった。

以上の臨床所見から，特に顕著な白血球の増数，しか もその多くが好中球幼若型に属する骨髄球, 後骨䯣球で あること，また触診上脾相当部に硬固感を触知できるこ となどから骨䯣性白血病が疑われた。

大量の輸液, 栄養補給により劣悪な全身症状の回復を 待って, 試験開腹を行ない, 腹腔内臟器腫瘤, 肝硬変な どとの類症鑑別をして，確診を得ようとした。むた抗白 血病剤としてマイトマイシンCの投与を試みようとする 治療方針を立てた。

\section{4. 治療 と経 過}

初訩時浔認められた極度の栄盖低下, 貧血, 出血傾向 などの症状を緩和する目的でデカドロン $1 \mathrm{mg} ，$ アドナ 
臨床

とコアグミンの止血剤，それにプラズマ $50 \mathrm{ml}$, 大量の ブドウ糖, 総合ビタミン剂の投与を行ない。 また, 抗白 血病凨として人にしばしば使用されるマイトマイシンC $1 \mathrm{mg}$ を1日和きに投与した。

これらの投薬を 5 日間継続したところ, 全身の戦慄が 消失し, また出血の傾向も著るしく改善され, 可視粘膜 貧血の程度もよく回復した。また呼吸困難の程度も軽く なるなど一般症状の改善が認められた。

このときの血液所見は赤血球数 $387 \times 10^{4}, \mathrm{Hb} 42 \%$, 白血球数 42,400 , 白血球百分比は, 好塩基球 0 , 好酸 球 1.5 , 骨䯣球 9.5 , 後骨髄球 22.5 , 好中球捍状核 34.5 , 分葉核 13.5 , リンパ球 18.0 , 単球 $0.5 \%$ (以上第 1 表) であった. そして臨床症状の改善が血液学的にも観察さ れた。

当日, 試験開腹を行なったところ, 脾は腫脹して巨大 となり, その表面は帯青兏褐色を呈し, 各汇胞は一様に 栗粒大まで腫大していた，また，その辺縁は鈍円を呈し 硬固であった。

第 5 病日以後はデカドロン $1 \mathrm{mg}$ の投与を中止し, プ レドニン $5 \mathrm{mg}$ に变えた。. またプラズマの投与は第 8 病 日で中止した。

第 10 病日に至ると、それまで弛張熱型を示していた 体温も $38.8^{\circ} \mathrm{C}$ と平熱に復し, 脈拍も 100 前後になった. 食欲も旺盛で鼻出血, 腹部の圧痛は消失し, 俥血もさら に回復し，心内雑音も少なくなった．しかしこのころか ら後肢に浮腫が出現した.

第 12 病日では体温 $38.5^{\circ} \mathrm{C}$, 脈拍 90 で, 後肢の浮腫 は依然持続したが，その他の症状は日ごとに軽くなって きた。またこのころになると病初にみられた運動時の転 倒は全く認められなくなった.この日に第 6 回目のマイ トマイシンCの投与を行ない本薬物使用量の限界に達し たと打もわれたので以後の本剂投与は中止した。 また血 液検査を実施したところ, 赤血球数 $457 \times 10^{4}, \mathrm{Hb} 41 \%$, 白血球数 28,900 , 百分比では, 好塩基球 0 , 好酸球 2.0 , 骨髄球 12.5 , 後骨髄球 17.0 , 好中球桿状核 28.5 , 分 葉核 19.0 , リンパ球 21.0 , 単球 $0 \%$ (第 1 表) で, 白 血球数の著明な減少が観察された。

第 13 病日には再び鼻出血が認妨にたが 3〜4 日で 消失した。この日からプレドニンを $2 \mathrm{mg}$ に減量した。

第 15 病日頃より触診にて脾臓が影著に縮少している ことが判明した。 こ机にともなって呼吸状態も正常に復 し, 腹部の膨満も漸次消失し, 圧痛も訴兄なくなった。 そして動作も活発となり食欲も旺盛になってきた。

第 17 病日には, 初猃時に見られた全身のふるえ, 心 内雑音, 血尿, 鼻出血, 呼吸困難, 腹部の圧痛, 膨満, 運動時の転倒, 全身僚急, 食欲廃絶等の主要症状はこと ごとく消失したが，ただ可視粘膜の貧血は依然存続して いた.この日でプレドニンの投与を中止した.
第 20 病日に至り, 体温 $39.2^{\circ} \mathrm{C}$ と昇し, 急性肺炎 症状を呈して, 再び呼吸困難が出現し, 脈拍数の増加, 鼻出血が認められ, 食欲も廃絶状態で, 全身症状の急激 な悪化が観察された。血液所見は赤血球数 $465 \times 10^{4}$, $\mathrm{Hb} 39 \%$, 白血球数 37,600 , 百分比では, 好塩基球 0 , 好酸球 1.0 , 骨䯣球 24.0 , 後骨䯣球 20.5 , 桿状核 32.0 , 分葉核 8.5, リンパ球 14.0 , 単球 $0 \%$ (第 1 表) であ った。使用限界量に達していたマイトマイシンCに代壳 て $6 \mathrm{Mp}$ (ロイケリン)を $75 \mathrm{mg} / \mathrm{day}$ とマイシリン 750 $\mathrm{mg}$ の投与を開始した.

21 病日以後は $40^{\circ} \mathrm{C}$ 以上の高熱が持続し, 脈拍数 130 前後と上昇し第 24 病日に心不全状態となって死亡した。

死亡直前の血液所見は赤血球数 $317 \times 10^{4}, \mathrm{Hb} 35 \%$ ， 白血球数 37,800 , 百分比: 好塩基球 0 , 好酸球 1.0 , 骨 髄球 31.5 , 後骨髄球 19.5 , 好中球桿状核 26.5 , 分葉 核 10.5 , リンパ球 9.0 , 単球 $2.0 \%$ (第 1 表) で, 総 蛋白量 $5.4 \mathrm{~g} / \mathrm{dl}$ ，コバルト反応 $\mathrm{R}_{6}$, 血清尿素態窒素 20 $\mathrm{mg} / \mathrm{dl}$, 尿所見は, 蛋白陽性・ベンス・ジョーンズ蛋白陽 性で, ビリルビン, ウロビリノーゲン, 糖はともに陰性 であった。

\section{5. 考察}

白血病の本態については人医関保6,7,8,11,12,13) におい て年毎に究明されつつあり, 各種の白血病に分類されて いる.

獣医関係では鷄にみられる本病はウイルスもその発症 因子となることが知られているが，な拈不明な点も多 い.

犬に打ける報告は少なく，A.C. AsBury (1957)3)は骨 䯣性白血病を報告している。それによれば慢性腸カター 儿を主徵とし，血液所見では白血球数 30 万を算し，叙 沫標本では $87 \%$ の好中球桿状核細胞が出現し, その大 部分が好中球であった事も強調している.

また赤血球 $480 \times 10^{4}, \quad \mathrm{Hb} 12.2 \mathrm{~g} / \mathrm{dl}$ と減少を示した と報告している。

今回, 著者が䛦療した本症例における血液所見は赤血 球数および $\mathrm{Hb}$ の減少, 白血数の顕著な增数, その百分 比では好中球の幼若型である骨髄球後骨䯣球の多数の出 現をみ，これは好中球桿状核や分葉核上り増多の傾向が 認められ,A.C. AsBURy と活涪同一の所見を観察したが, 本例は遺憾ながら，畜主の了解がえられず，剖検および 病理学的検索を実施できなかったが，本症例も慢性骨䯣 性白血病に類似した白血病性の疾患であると思われる。

な抢, フイラリア症の症状発現期, 腫瘍患犬との類症 鑑別は血液検査を加えて詳細に検討することが望まし い.また白血病は老令犬においては興味ある疾病の一つ であると考学れる。 


\section{6. 結語招よび要約}

患犬はドイッ・シェパード種，ㅇ， 5 才で，昭和 41 年 2 月に歩行時転倒, 血尿, 呼吸困難などの症状を呈し, 某獣医師によってフィラリア症の診断のもとに治療をう け，一時回復したが，その後，漸次削度が目立ち，消化 不良性の軟便が続き，栄養は低下寸るばかりであっ望。

42 年 3 月飞本例を初診し，当時荅白ともいうべき著明 な口腔粘膜, 結膜の䂓血, 呼吸困難, 鼻出血を呈し, は なはだしく削瘦していた。また歩行中転倒することもし ばしば見られ，触診によって最後位肋骨の後縁に沿って 硬固な腫瘤を触れ該部を圧すると疼痛を訴えた。これは 第 5 病日の試験開腹の結果巨大な脾腫を確認した.

血液検查を実施したところ, 赤血球数, $\mathrm{Hb}$ ともに減 少し, 白血球数 89,700 と著明僧加し, そのうち, 好 中球幼若型汇属する骨䯣球, 後骨䯣球が半数を占めてい た. 肝機能検查として試みたコバルト反応は右側反応を 示し, 血清蛋白は減少していた。

尿検査では, 糖, ウロビリノーゲン, ビリルビンは陰 性であり，参考汇試みたベンス・ジョンズ蛋白体は陽性 であった。またミクロフイラリアむ検出され，フィラリ アによる障害も少なからず関与しているように扔もわれ た.

治療は栄養改善の目的でプラズマ, ブドウ糖, 総合ビ タミン剂を軏日投与し，抗白血病版としてプレドニン 1
〜 $5 \mathrm{mg}$ を每日，マイトマイシンC $1 \mathrm{mg}$ 学1日和きに 投与したところ漸次症状の改善が認められ，第 17 病日 には汪とんど回復したが和もわれたが，第 20 病日に いたり，急性肺炎を併発し，原病であると思われたいわ ゆる白血病の急性転帰をとり, 一般症状は再び悪化して 第 24 病日に死亡した. 解剖就よび病理学的検索を実施 することができなかったが，以上の所見から骨䯣性白血 病がうたがわれた。

稿を終るにあたり，御校閲をいただい㣽，麻布獣医科 大学，深野高正教授汇厚く謝意を表する。

$$
\text { 文献 }
$$

1）鳥潟 勲：日獣会誌，3，9，285 (1950)。2) 石谷類造, 外：日獣会誌， 9, 242 (1956). 3) AsBuRY A.C.: M.S.U. Vet. 17, 182 (1958)。 4) 高瀬七郎 : 獣畜誌，227，321 (1958)。 5) 安田純夫：『家畜 外科学, 399, 南江堂 (1960). 6) 平木 潔: 治療, 40, 1343(1958). 7) 長村重之: 治療, 42, 2097(1960). 8) 三方一沢, 外: 内科治療医典, 425, 南山堂 (1962). 9）小宫悦造：臨床血液学，412，南山堂 (1962)。10) 福井定光, 外: 䛦療, 19, 1572 (1962).

11) 田中教英：内科，16，777(1965)，12）内科臨 㕅討議会：内科，18，106 (1966)。13）太田和雄：内 科, 19，1256 (1967). 14）中村良一：獣医宝典, 盖 賢堂，92（1952）。15）其田三夫，外：日獣会誌，12， 397 (1959)。16) 藤井, 外：日獣会誌, 19, 557(1966).

(493 ページよりつづく)

Outbreaks of Bovine Epizootic Fever in Japan in 1966

Y. Inaba Y. Tanaka, K. Sato, T. Omori, *H. Ito and **K. Okazaki

(Natinal Institute of Animal Health, *Nippon Veterinary and Zootechnical College, and

**Livestock Sanitation Section, Bureau of Animal Industry, Ministry of Agriculture and Forestry)

SUMMARY

A bovine disease of unknown etiology broke out in six prefectures of Japan, Fukuoka, Hiroshima, Nagasaki, Saga, Shimane, and Yamaguchi, in October and November, 1966. Its main symptoms consisted of transient high fever $\left(40.0\right.$ to $\left.42.0^{\circ} \mathrm{C}\right)$, polypnea, anorexia, loss of vigor, lacrimation, salivation, arthralgia, and tremor of muscles. About 7,000 cattle were affected with this disease.

Strains Nagasaki and Yamaguchi were developed from defibrinated blood harvested from some affected cattle at the febrile stage. They were successfully subjected to serial passages in cattle. From the results of an infection prevention experiment with cattle, they were identified as strains of bovine epizootic fever virus.
A survey of antibodies against known viruses was conducted on acute-stage and convalescent sera collected from naturally infected cattle and pre- and post-inoculation sera from experimentally infected cattle. As a result, a significant increase in antibody titer was shown by all the sera tested against strain YHK of bovine epizootic fever virus (BHK 21-W2 cell-passaged virus), but not by any of the sera against bovine influenza Kaeishi virus, bovine diarrhea virus, bovine infections rhinotracheitis virus, the Fukuroi type of bovine adenovirus, or type 3 of parainfluenza virus. In conclusion, it was presumed that bovine epizootic fever virus might have played a principal role in the present outbreaks in Japan. 